\title{
THE MODERATING EFFECT OF COMPETITIVE STRATEGIES ON INTELECTUAL CAPITAL AND COMPANY VALUE IN BANKING COMPANIES
}

\author{
Rumini $^{1}$, Bambang Sugiharto ${ }^{1}$,Asep Kurniawan ${ }^{1}$ \\ ${ }^{1}$ Sekolah Tinggi IImu Ekonomi Sutaatmadja, Indonesia \\ Email : bambangsugihart@gmail.com \\ Email :asep@stiesa.ac.id
}

\begin{tabular}{|c|c|}
\hline INFO ARTIKEL & ABSTRAK/ABSTRACK \\
\hline $\begin{array}{l}\text { Histori Artikel : } \\
\text { Tgl. Masuk : } 18 \text { Maret } 2019 \\
\text { Tgl. Diterima: } 26 \text { Maret } \\
2019 \\
\text { Tersedia Online } 29 \text { Maret } \\
2019 \\
\text { Keywords: } \\
\text { Intellectual Capital , } \\
\text { Company Value and } \\
\text { Competitive Strategy }\end{array}$ & 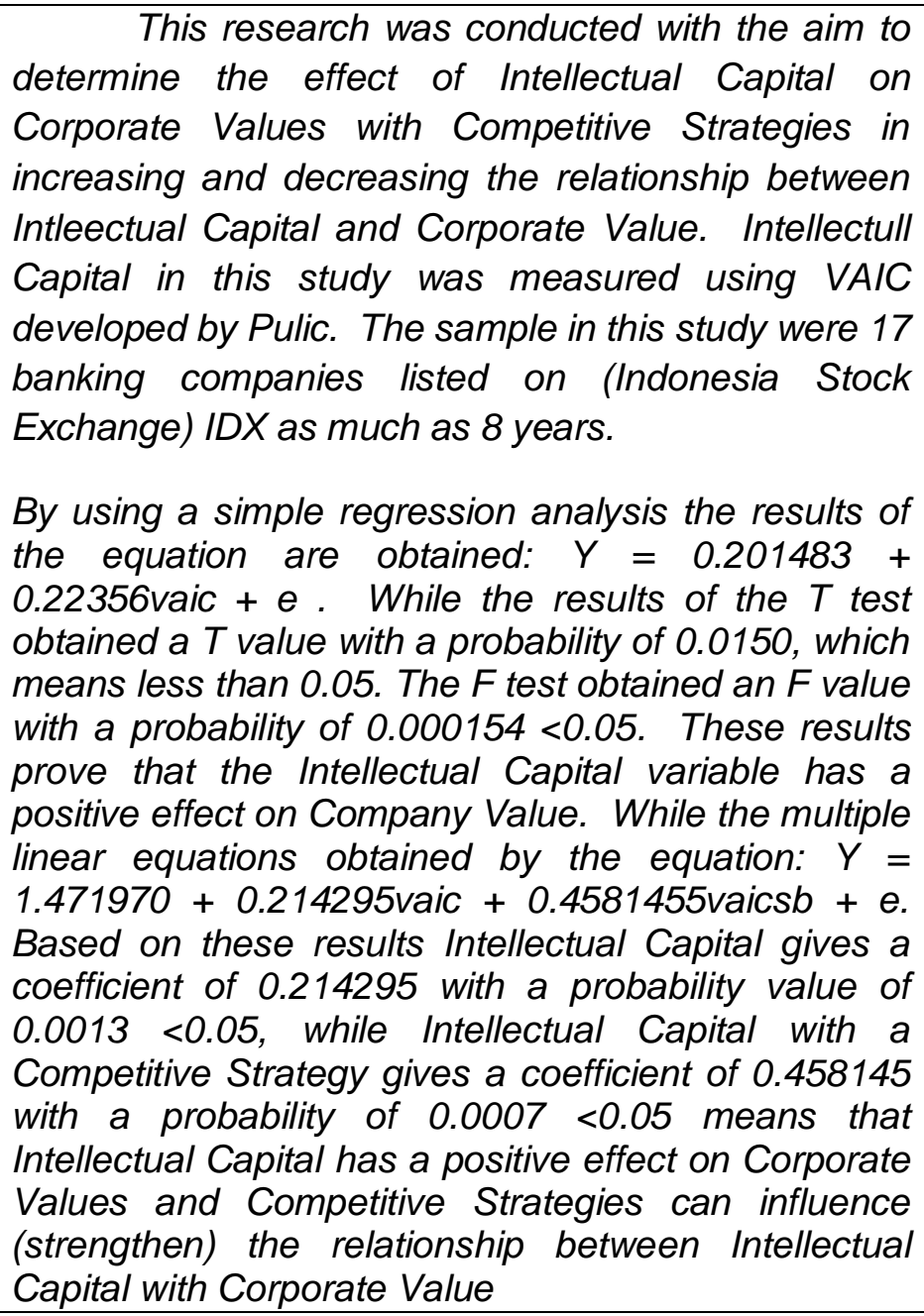 \\
\hline
\end{tabular}

\section{PENDAHULUAN}

Globalisasi, inovasi teknologi dan persaingan yang ketat pada abad ini memaksa perusahaan-perusahaan mengubah cara mereka dalam menjalankan bisnisnya. Agar dapat terus bertahan perusahaan-perusahaan mengubah bisnisnya dari yang didasarkan pada tenaga kerja (labor-based business) menuju knowledge based business (bisnis berdasarkan pengetahuan), dengan karakteristik utama ilmu pengetahuan (Sawarjuwono dan Kadir, 2003).

Labor-based business memegang prinsip perusahaan padat karya, dalam artian semakin banyak karyawan yang 
dimiliki perusahaan maka akan meningkatkan produktivitas perusahaan sehingga perusahaan dapat berkembang. Sedangkan perusahaan - perusahaan yang menerapkan knowledge based business akan menciptakan suatu cara untuk mengelola pengetahuan (manajemen pengetahuan) sebagai sarana untuk memperoleh penghasilan perusahaan. Sesuai dengan resource based theory (Wernerfelt, 1984: 174) yang menyatakan bahwa keberadaan sumber daya perusahaan merupakan pemicu di balik keunggulan bersaing dan kinerja. $\mathrm{Hal}$ ini secara tidak langsung juga memaksa perusahaan untuk mengubah strategi bisnisnya, dari bisnis yang berdasarkan tenaga kerja (labor based business) menjadi berdasarkan pengetahuan (knowledge based business). Perusahaan yang menerapkan strategi knowledge based business ini harus dapat menciptakan nilai tambah dengan mengelola the hidden value (nilai-nilai tidak tampak) yang ada pada asset tidak berwujud. Salah satu pendekatan yang digunakan dalam penilaian dan pengukuran aset tidak berwujud adalah melalui Intellectual Capital (Guthrie, 2000), dengan tujuan utama memperoleh keunggulan bersaing.

Berkembangnya perusahaan akan bergantung pada bagaimana kemampuan manajemen untuk mengolah sumber daya perusahaan dalam menciptakan nilai perusahaan sehingga akan memberikan kegungulan kompetitif perusahaan yang berkelanjutan. Pada umumnya, perusahaan - perusahaan di Indonesia masih menggunakan akuntansi tradisional yang menekankan pada penggunaan tangible asset. Padahal, dengan adanya perubahan lingkungan bisnis menjadi knowledge based business, tangible asset menjadi kurang penting dibandingkan dengan intangible asset. Laporan keuangan tradisional tidak mampu menyajikan informasi mengenai knowledge based processes dan intangble asset. Hal tersebut menjadikan laporan keuangan tradisional tidak mampu menyajikan informasi yang cukup tentang kemampuan perusahaan untuk menciptakan nilai.

Keterbatasan laporan keuangan dalam menjelaskan nilai perusahaan mengakibatkan pelaporan keuangan seringkali dianggap kurang memadai sebagai pelaporan kinerja keuangan. Dengan kata lain, informasi akuntansi tidak dapat digunakan dalam pembuatan keputusan investasi dan kredit. Seharusnya ada informasi lain yang perlu disampaikan kepada para pengguna laporan keuangan sehingga dapat menjelaskan nilai lebih yang dimiliki perusahaan. Seperti yang diungkapkan Canibano et al. (2000) bahwa salah satu tanda informasi akuntansi tidak dapat dijadikan landasan dalam membuat keputusan adalah semakin meningkatnya kesenjangan antara nilai pasar dan nilai buku ekuitas perusahaan dalam financial market. Meningkatnya perbedaan antara nilai pasar dan nilai buku perusahaan telah menarik para peneliti untuk menyelidiki nilai yang hilang (hidden value) pada laporan keuangan perusahaan.

Informasi mengenai intellectual capital menjadi informasi yang bernilai untuk diketahui investor karena di era globalisasi ini, adanya pengungkapan intellectual capital di dalam laporan keuangan perusahaan memiliki peran yang cukup besar dalam meningkatkan nilai perusahaan (Pulic,1998; Bontis, 2001). Semua informasi tersebut sangat penting bagi investor dalam pengambilan keputusan investasi. Apabila informasi mengenai nilai perusahaan yang dilaporkan dalam laporan keuangan ini tidak lengkap dan kemudian digunakan oleh investor untuk mengambil keputusan maka akan menjadi bahan pertimbangan yang salah. Oleh karena itu, diperlukan suatu metode untuk mengidentifikasi intellectual capital agar informasi mengenai nilai perusahaan dalam laporan keuangan tersebut lengkap dan dapat menjadi bahan pertimbangan yang baik bagi investor dalam mengambil keputusan investasi yang tepat. 
Lev (2001, p.9) dalam Chen et al (2005) mencatat bahwa selama tahun 1977 - 2001, dalam US Standard and Poors (S \& P) 500, rasio nilai pasar terhadap nilai buku perusahaan meningkat dari 1 sampai 5 . Hal ini menyatakan secara tidak langsung bahwa sekitar $80 \%$ nilai pasar perusahaan tidak tercermin dalam laporan keuangan. Menurut Edvinsson dan Malone (1997) dalam Chen et al (2005) perbedaan antara nilai pasar dan nilai buku perusahaan adalah nilai Intellectual Capital (IC).

Firer dan Williams, (2003) mendefinisikan Intellectual capital sebagai kekayaan perusahaan yang merupakan kekuatan dibalik penciptaan nilai perusahaan. Intellectual capital terdiri dari 3 komponen yaitu, Human Capital(HC), Customer Capital (CC), dan Structural Capital (SC). Sigit dan Silvia, (2013) dalam penelitiannya menyebutkan bahwa human capital, customer capital, dan structural capital memiliki kapasitas yang berbedabeda dan kontribusi yang berbeda-beda pula.

Bertolak belakang dengan meningkatnya pengakuan IC dalam mendorong nilai dan keunggulan kompetitif perusahaan, pengukuran yang tepat terhadap IC perusahaan belum dapat ditetapkan. Misalnya, Pulic (1998; 1999; 2000) tidak mengukur secara langsung IC perusahaan, tetapi mengajukan suatu ukuran untuk menilai efisiensi dari nilai tambah sebagai hasil dari kemampuan intelektual perusahaan (Value Added Intellectual Coefficient VAIC). Komponen utama dari VAIC dapat dilihat dari sumber daya perusahaan, yaitu physical capital (VACA - value added capital employed), human capital (VAHUvalue added human capital), dan structural capital (STVA - structural capital value added).

Menurut Pulic (1998) dalam Ulum (2007), tujuan utama dalam ekonomi yang berbasis pengetahuan adalah untuk penciptakan value added. Sedangkan untuk dapat menciptakan value added dibutuhkan ukuran yang tepat tentang physical capital (yaitu dana-dana keuangan) dan intellectual potential (direpresentasikan oleh karyawan dengan segala potensi dan kemapuan yang melekat pada mereka). Lebih lanjut Pulic (1998) dalam Ulum (2007) menyatakan bahwa intellectual ability (yang kemudian disebut dengan VAIC) menunjukkan bagaimana kedua sumber daya tersebut (physical capital dan intellectual potential) telah secara efisiensi dimanfaatkan oleh perusahaan.

Pengelolaan intellectual capital semakin penting untuk dilakukan dalam era knowledge economy sekarang ini, apalagi diterapkan dalam sektor perbankan. Pemilihan sektor perbankan sebagai sampel mengacu pada penelitian Kamath (2006); Mavridis (2005); Firer dan William (2003). Sektor perbankan dipilih karena merupakan salah satu sektor yang paling intensif IC-nya. Selain itu, dari aspek intelektual, secara keseluruhan karyawan di sektor perbankan lebih homogen dibandingkan dengan sektor ekonomi lainnya (Kubo dan Saka, 2002). Selain itu jika dilihat dari komponen pembentuknya, komponen karyawan (human) pada bank merupakan unsur utama sebab seluruh kegiatan pada bank menggunakan karyawan sepenuhnya, berbeda dengan perusahaan manufaktur yang memiliki komponen terbesar selain pada karyawan yaitu pada mesin dan alatalat (fixed assets) untuk memproduksi barang.

Salah satu jenis industri yang paling intensif penggunaan intellectual capital adalah industri jasa perbankan. Sektor perbankan, memiliki peranan yang sangat vital terutama dalam mendukung pergerakan serta pertumbuhan ekonomi di suatu negara. Hal ini mengakibatkan sengitnya persaingan dalam industri perbankan itu sendiri dalam menyediakan layanan yang terdepan bagi konsumen. Dalam persaingan yang begitu ketat, tidaklah jarang memancing tenaga-tenaga intelek suatu perusahaan untuk berpindah pada perusahaan saingan dalam mempertahankan keunggulan bersaing atas perusahaan sejenis lainnya. 
Konsep intellectual capital telah mendapatkan perhatian besar dari berbagai kalangan terutama para akuntan dan akademisi. Fenomena ini menuntut mereka untuk mencari informasi yang lebih rinci mengenai hal-hal yang berkaitan dengan pengelolaan intellectual capital. Mulai dari cara pengidentifikasian, pengukuran sampai dengan pengungkapan IC dalam laporan keuangan perusahaan. Intellectual capital dapat dipandang sebagai pengetahuan, dalam pembentukan kekayaan intelektual dan pengalaman yang dapat digunakan untuk menciptakan kekayaan (Stewart, 1997). Pengelolaan intellectual capital yang baik diharapkan akan mampu meningkatkan nilai perusahaan.

Tujuan penelitian ini ialah menguji secara empiris pengaruh intellectual capital pada nilai perusahaan. Intellectual capital diukur dengan The Value Added Intelectual Coefficient (VAIC) yang dikembangkan oleh Pulic (1998). Sedangkan ukuran nilai perusahaan menggunakan rasio price book value (PBV) yang merupakan perbandingan antara harga saham dengan nilai buku per lembar saham (Ang, 1997). Dan juga ingin mengetahui pada perusahaan perbankan, apakah intellectual capital berpengaruh atau tidak terhadap nilai perusahaan, dan bagaimana signifikansinya. Diharapkan hasil penelitian dapat dijadikan sebagai referensi bagi investor dan calon investor untuk melakukan kebijakan investasi.

\section{KERANGKA TEORITIS DAN PENGEMBANGAN HIPOTESIS}

1. Pengaruh Intellectual Capital terhadap Nilai Perusahaan

Menurut teori stakeholder, dijelaskan bahwa seluruh aktivitas perusahaan bermuara pada penciptaan nilai/value creation. Para stakeholder akan lebih menghargai perusahaan yang mampu menciptakan nilai karena dengan penciptaan nilai yang baik, maka perusahaan akan lebih mampu untuk memenuhi kepentingan seluruh stakeholder. Dalam konteks IC, penciptaan nilai dilakukan dengan memaksimalkan pemanfaatan unsurunsur IC yaitu human capital, physical capital, maupun structural capital.

Penelitian Chen et al. (2005), menyatakan bahwa investor cenderung akan membayar lebih tinggi atas saham perusahaan yang memiliki sumber daya intelektual yang lebih dibandingkan perusahaan dengan sumber daya intelektual yang rendah. Harga yang dibayar oleh investor tersebut mencerminkan nilai perusahaan. Market value terjadi karena masuknya konsep modal intelektual yang merupakan faktor utama yang dapat meningkatkan nilai suatu perusahaan (Abidin, 2000). Dalam hubungannya dengan teori stakeholder, dijelaskan bahwa seluruh aktivitas perusahaan bermuara pada penciptaan nilai/value creation. Kepemilikan serta pemanfaatan sumber daya intelektual memungkinkan perusahaan mencapai keunggulan bersaing dan nilai tambah. Investor akan memberikan penghargaan lebih kepada perusahaan yang mampu menciptakan nilai tambah secara berkesinambungan.

Intellectual Capital diyakini dapat meningkatkan nilai bagi perusahaan. Hal ini dibuktikan oleh putra (2010), Darmawan danToro (2012), dan dan Yunita (2012). Berdasarkan teori dan diperkuat dengan hasil penelitian tersebut, maka hipotesis yang diajukan dalam penelitian ini adalah :

H1 : Intellectual Capital berpengaruh positif terhadap nilai perusahaan.

2. Pengaruh Intellectual Capital terhadap Nilai Perusahaan dengan Strategi Bersaing Sebagai Pemoderasi

Sebelum menerapkan strategi perusahaan harus terlebih dahulu melakukan perumusan strategi, perusahaan harus memahami terlebih dahulu apa saja yang mereka miliki. Karena menurut Barney (1991) sumber daya yang dimiliki perusahaan akan membentuk landasan bagi strategi perusahaan. Perusahaan menggunakan sumber daya berupa aset tidak berwujud dan aset berwujudnya untuk 
mengembangkan

dan mengimplementasikan strategi (Chusnah et al,. 2014).

Anatan dan Eliton (2005) mengenai strategi inovasi dan kinerja operasional perusahaan dengan melakukan review aplikasi intellectual capital management dalam era baru manufaktur. Dalam penelitian tersebut dikemukakan proposisi bahwa dengan implementasi strategi inovasi yang tepat dalam perusahaan akan mempengaruhi pencapaian keunggulan kompetitif perusahaan.

Dalam penelitian Tewal (2010) diuji pengaruh strategi bersaing dan inovasi terhadap kinerja perusahaan perhotelan di Sulawesi Utara. Penelitian tersebut menunjukan bahwa strategi bersaing perusahaan perhotelan di Sulawesi Utara berpengaruh signifikan terhadap kinerja perusahaan. Meskipun dala penelitian Tewal (2010) tersebut strategi bersaing tidak dijadikan variabel moderasi, namun hal ini dapat dijadikan acuan bahwa dengan mengimplentasikan strategi bersaing dan inovasi perusahaan dapat meningkatkan kinerjanya, dimana nantinya akan berdampak pada nilai perusahaan. Apalagi bila perusahaan tersebut memiliki tingkat intellectual capital yang tinggi. Menurut penelitian diatas maka hipotesis yang diajukan ini adalah :

$\mathrm{H} 2$ : Hubungan antara nilai Intellectual Capital dan nilai perusahaan dipengaruhi strategi bersaing

\section{METODOLOGI PENELITIAN Objek Penelitian}

Penelitian ini di lakukan dengan mengambil data berupa laporan tahunan perusahaan yang secara konsisten terdaftar di Bursa Efek Indonesia (BEI) pada tahun 2010-2017. Data tersebut diambil dari website www.idx.co.id.

\section{Populasi dan Sampel}

Populasi adalah semua bagian atau anggota dari objek yang akan diamati. Populasi bisa berupa orang, benda, objek, peristiwa, atau apapun yang menjadi objek dari survey kita. Populasi yang digunakan untuk penelitian ini adalah Bank Umum yang terdaftar di Bursa Efek Indonesia (BEI) pada tahun 2010-2017. Penelitian menggunakan Purposive Sampling yaitu sampel di pilih berdasarkan kriteria dibawah ini :

1. Bank Umum yang secara konsisten terdaftar di Bursa Efek Indonesia (BEI).

2. Periode penelitian berlangsung dari tahun 2010-2017.

3. Menggunakan laporan tahunan (disajikan dalam rupiah) Bank umum yang diteliti.

\section{Jenis Penelitian}

Jenis penelitian yang digunakan kuantitatif. Penelitian kuantitatif yaitu penelitian yang menekankan pada pengujian teori-teori melalui variabelvariabel penelitian dalam angka-angka, dan melakukan analisis data dengan prosedur statistika dan permodalan matematis. Penelitian ini menggunakan data laporan tahunan bank di Bursa Efek Indonesia (BEI) pada tahun 2010-2017.

\section{Metode Pengumpulan Data}

Metode pengumpulan data yang peneliti gunakan diperoleh dari berbagai cara, yaitu :

1. Penelitian Kepustakaan (Library Research)

Penelitian Kepustakaan

(Library Research) yaitu metode pengumpulan data mengenai hal-hal yang berkaitan dengan penelitian yang diperoleh dengan cara membaca buku-buku, skripsi, jurnal, dan tesis. Metode ini digunakan peneliti untuk dapat memperoleh landasan dan konsep dalam penelitian ini.

2. Penelitian Lapangan (Field Research)

Data sekunder yang digunakan dalam penelitian ini bersumber dari laporan tahunan bank di Indonesia pada tahun 2008 sampai 2015 yang telah dipublikasikan secara lengkap di www.idx.co.id.

\section{Teknik Analisis Data}


Teknik analisis data yang digunakan dalam penelitian ini adalah model analisis regresi data panel. Data panel adalah kumpulan data yang terdiri atas data seksi silang (beberapa variabel) dan data runtut waktu (berdasarkan waktu).

Setelah melakukan pemilihan sampel, dan menentukan variabel-variabel yang digunakan dalam penelitian, langkah selanjutnya adalah melakukan pengolahan data dengan menggunakan analisis regresi untuk menguji hipotesis. Untuk membantu penelitian, peneliti akan menggunakan software pengolahan data Microsoft Excel dan program Eviews 9, kelebihan dari program EViews 9 sendiri adalah kemudahan penggunaan dan menyediakan fasilitas metode estimasi regresi yang lebih lengkap dibandingkan software lain.

\section{Variabel Penelitian}

Ada tiga variabel penelitian yang digunakan dalam penelitian ini yaitu variabel independen, dependen dan moderasi :

\section{Analisis Data}

Dalam penelitian ini terdapat beberapa tahapan dalam menjelaskan hasil penelitian, untuk menggambarkan setiap variabel akan dijelaskan dalam analisis deskriptif. Tahap selanjutnya melakukan pembuatan model menggunakan analisis regresi data panel, setelah diperoleh model maka ditentukan model terbaik berdasarkan tiga uji pemilihan model yaitu Chow Test, Langrange Multiplier dan Hausman Test. Kemudian dilakukan uji asumsi klasik untuk menguji kelayakan model regresi yang diteliti terdiri dari tiga jenis, yakni uji Normalitas, uji Heterokedastisitas dan uji Autokorelasi. Setelah memenuhi uji asumsi klasik maka dilakukan penarikan kesimpulan dengan menguji hipotesis yang diajukan dalam penelitian ini.

\section{HASIL DAN PEMBAHASAN}

Data dalam penelitian ini adalah perusahaan perbankan yang konsisten terdaftar di BEI (Bursa Efek Indonesia). Sampel perusahaan yang berhasil di peroleh menurut kriteria ditunjukan dalam tabel berikut ini :

Tabel 4.1

Penentuan sampel penelitian

\begin{tabular}{|c|l|c|}
\hline No & Kriteria & $\begin{array}{c}\text { Jumlah } \\
\text { Perusahaan }\end{array}$ \\
\hline 1 & $\begin{array}{l}\text { Bank yang secara } \\
\text { konsisten terdaftar di } \\
\text { Bursa Efek Indonesia } \\
\text { BEl) pada tahun 2010- } \\
2017\end{array}$ & 26 \\
\hline 2 & $\begin{array}{l}\text { Bank yang tidak } \\
\text { menggunakan mata } \\
\text { uang rupiah dalam } \\
\text { laporan tahunan }\end{array}$ \\
\hline 3 & $\begin{array}{l}\text { Bank yang tidak } \\
\text { memiliki laporan } \\
\text { tahunan lengkap dari } \\
\text { tahun 2010-2017 }\end{array}$ \\
\hline 4 & $\begin{array}{l}\text { Bank yang memenuhi } \\
\text { kriteria }\end{array}$ \\
\hline 5 & $\begin{array}{l}\text { Bank dengan periode } \\
\text { waktu 8 tahun }\end{array}$ \\
\hline 5 & $\begin{array}{l}\text { Total sampel penelitian } \\
\text { dari tahun 2010-2017 }\end{array}$ \\
\hline
\end{tabular}

\section{Sumber data yang diolah penulis,2018}

Berdasarkan tabel diatas dapat dikatakan bahwa dari semua perusahaan perbankan yang terdaftar di BEI hanya 17 perusahaan yang memenuhi kriteria peneliti. Selain itu data ini berbentuk time series, dengan 8 tahun masa observasi dan data cross section sebanyak 20 perusahaan sehingga data panel yang digunakan atau yang dimiliki sebanyak $136(17 \times 8)$.

Analisis statistik digunakan untuk mengetahui gambaran atau deskripsii tentang masing-masing variabel yang terkait dengan penelitian. Dalam penelitian ini digunakan data dalam bentuk pooled data. Jumlah sampel yang terdapat dalam penelitian ini yaitu sebanyak 17 perusahaan perbankan yang terdaftar di 
BEI dan penelitian dilakukan selama 8 tahun yaitu mulai tahun 2010 sampai tahun 2017, sehingga diperoleh data pengamatan sebanyak 17 perusahaan $\times 8$ tahun penelitian $=136$ data yang diperoleh secara pooled data.

Variabel independen pada penelitian ini adalah intellectual capital sedangkan variabel dependen adalah nilai perusahaan dan strategi bersaing sebagai variabel pemoderasi Berikut ini adalah gambaran statistik deskriptif dari variabelvariabel yang diteliti. Nilai Perusahaan (Price Book Value)

Hasil analisis deskriptif variabel nilai perusahaan menunjukan bahwa dari 136 observasi nilai perusahaan yang terbesar sebesar 4.690000 yaitu pada perusahaan PT Bank Central Asia Tbk (BBCA) pada tahun 2011 sedangkan perusahaan yang terkecil sebesar 0.00000 pada perusahaan PT QNB Indonesia Tbk (BKSW) tahun 2016. Kemudian rata-rata dari nilai perusahaan adalah 1.563676, standar deviasi atau sebaran data sebesar 0.991377, Jarque-Bera dari variabel nilai perusahaan adalah 31.90156 lebih besar dari 5,99 (df 2 dengan alpha 5\%) atau nilai probabilitas 0.000000 (lebih kecil dari 5\%) maka variabel nilai perusahaan memiliki data yang tidak berdistribusi normal.

\section{a. Intellectual Capital (VAIC)}

Hasil analisis deskriptif
variabel intellectual capital menunjukan bahwa dari 136 observasi nilai perusahaan yang terbesar sebesar 7.145070 yaitu pada perusahaan PT Bank Bumi Arta Tbk (BNBA) pada tahun 2017 sedangkan perusahaan yang terkecil sebesar -0.627957 pada perusahaan PT Bank MNC Internasional Tbk (BABP) tahun 2016. Kemudian rata-rata dari intellectual capital adalah 2.782021, standar deviasi atau sebaran data sebesar 1.194796, Jarque-Bera dari variabel intellectual capital adalah 56.06214 lebih besar dari 5,99 (df 2 dengan alpha 5\%) atau nilai probabilitas 0.000000 (lebih kecil dari $5 \%$ ) maka variabel intellectual capital memiliki data yang tidak berdistribusi normal.

b. Strategi Bersaing (Biaya penelitian, pendidikan dan pengembangan/total sales revenue)

Hasil analisis variabel strategi bersaing menunjukan bahwa dari 136 observasi nilai yang terbesar adalah 0.170164 sedangkan yang terkecil adalah 0.000384 . kemudian rata-rata dari strategi bersaing adalah 0.008928 , standar deviasi atau sebaran data sebesar 0.017477, Jarque-Bera dari variabel strategi bersaing adalah 20274.03 lebih besar dari 5,99 (df 2 dengan alpha 5\%) atau nilai probabilitas 0.000000 (lebih kecil dari 5\%) maka variabel strategi bersaing memiliki data yang tidak berdistribusi normal.

\section{Analisis Regresi Data Panel}

Dalam membuat estimasi data panel, langkah yang pertama dilakukan adalah membuat pemodelan yang terdiri dari Common Effect Model, Fixed Effect Model dan Random Effect Model. Kemudian dilakukan Pemilihan model regresi data panel terbaik dengan menggunakan tiga test yaitu sebagai berikut:

1. Chow Test/F Test

Uji ini dilakukan untuk memilih salah satu model pada regresi data panel yaitu antara model Common Effect dan Fixed Effect. Ketentuan yang akan digunakan dalam pengambilan kesimpulan $F$ Test dapat dilakukan sebagai berikut:

a. Jika nilai probabilitas $\mathrm{F}<0.05$ maka $\mathrm{H}_{0}$ ditolak atau menerima $\mathrm{H}_{1}$ (FEM)

b. Jika nilai probabilitas $F>0.05$ maka $\mathrm{H}_{0}$ gagal ditolak (CEM)

Hipotesis:

$\mathrm{H}_{0}$ : Common Effect Model

$\mathrm{H}_{1}$ : : Fixed Effect Model

2. Hausman Test 
Hausman test dilakukan untuk menguji model terbaik antara Fixed Effect Model dengan Random Effect Model. Dalam penarikan hasil dilakukan dengan membandingkan nilai $\mathrm{F}$ probabilitas dengan $\alpha$, jika nilai $F$ probabilitas $<0.05$ yang ditentukann, maka $\mathrm{H}_{0}$ ditolak, dan sebaliknya jika jika nilai F-probabilitas $>0.05$, maka $\mathrm{H}_{0}$ diterima. Hipotesisnya sebagai berikut: $\mathrm{H}_{0}$ : Random Effect Model

$\mathrm{H}_{1} \quad$ : $\quad$ Fixed Effect Model

Berdasarkan hasil hausman test pada tabel diatas model 1 dan model 2 , didapatkan probabilitas Fmodel 1 sebesar 0.1267 dan model 2 sebesar 0.5101 . Hasil hausman test menunjukkan bahwa probabilitas $\mathrm{F}>0.05$ artinya $\mathrm{H}_{0}$ diterima, sehingga model yang terbaik menurut hausman test adalah Random Effect Model.

Dari dua uji pemilihan model dapat di simpulkan bahwa model RE lebih baik dari model FE dan CE. Menurut Gujarati dan Porter (2009), persamaan yang memenuhi asumsi klasik hanya persamaan yang menggunakan metode Generalized Least Square (GLS). Dalam eviews model estimasi yang menggunakan metode GLS hanya random effect model, sedangkan fixed effect dan common effect menggunakan Ordinary Least Square (OLS). Dengan demikian berdasarkan pemilihan model estimasi yang terpilih diatas adalah random effect model maka tidak perlu di lakukan uji asumsi klasik.

Berikut tabel model Random Effect :

\section{Pengujian Hipotesis}

\section{Analisis Regresi Sederhana}

Analisis regresi linier adalah studi bagaimana satu variabel dependen dipengaruhi oleh satu atau lebih dari variabel lain yaitu variabel independen dengan tujuan untuk mengestimasi atau memprediksi nilai rata-rata variabel dependen didasarkan pada nilai variabel independen yang diketahui. Dengan demikian, tujuan utama regresi adalah untuk memprediksi nilai variabel dependen berdasarkan satu atau lebih variabel independen (Widarjono, 2010)

Berdasarkan banyaknya variabel dependen, regresi dibagi menjadi dua jenis yaitu regresi sederhana dan regresi berganda. Regresi sederhana hanya terdiri dari satu variabel independen sedangkan regresi berganda lebih dari satu variabel independen.

Maka diperoleh dua persamaan :

$\mathrm{Y}=\mathrm{a}+\mathrm{b} 1 \mathrm{x} 1+\mathrm{e}$.

(1)

Keterangan :

$\begin{array}{lll}\text { Y } & : & \text { Nilai Perusahaan } \\ \text { a } & : & \text { Konstanta } \\ \text { b1 } & : & \text { Koefisien regresi } \\ \text { x1 } & : & \text { Intellectual Capital } \\ \text { e } & : & \text { Error }\end{array}$

Persamaan hipotesis kedua melibatkan variabel moderating :

$$
Y=a+b 1 \times 1+b 2 \times 1 \times 2+e .
$$

(2)

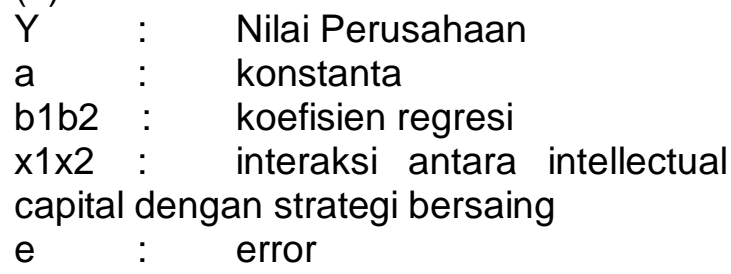

\section{Hasil Estimasi Model 1 data panel pengaruh Intellectual Capital terhadap Nilai Perusahaan}

Koefisien regresi $\mathrm{X} 1$ sebesar 0.022356 artinya Intellectual Capital (VAIC) berpengaruh positif terhadap nilai perusahaan. Hal ini menunjukan bahwa dengan penambahann satu satuan intellectual capital akan terjadi kenaikan nilai perusahaan sebesar 0.022356

\section{Uji Signifikan Parameter Individual (Uji Statistik t) Model 1}

Uji statistik $t$ dilakukan untuk mengetahui sebesrapa besar pengaruh satu variabel independen secara individu dalam menerangkan variabel-variabel dependen. Penelitian ini menggunakan tingkat signifikansi $5 \%$ atau sebesar 0,05. Berikut output hasil uji statistik parsial (uji t) : 
Hipotesis pertama Ho ditolak artinya variabel intellectual capital berpengaruh secara signifikan terhadap nilai perusahaan yang ditunjukkan dengan nilai probabilitas lebih kecil dari pada $\alpha 5 \%$ $(0.0150>0.05)$.

\section{Uji Signifikansi Simultan (F-test) Model 1}

Secara sederhana $\mathrm{F}$ test dilakukan untuk menunjukkan apakah semua variabel independen atau bebas yang dimasukkan dalam model mempunyai pengaruh terhadap variabel dependen. Output uji signifikansi simultan diinterpretasikan dalam tabel 4.8. sebagaimana yang dipaparkan sebelumnya bahwa hipotesis yang diajukan pada uji-F adalah sebagai berikut:

$\begin{aligned} \mathrm{H}_{0}: & \begin{array}{l}\text { Variabel independen tidak } \\ \text { berpengaruh terhadap variable } \\ \text { dependen. }\end{array}\end{aligned}$

$H_{1}$ : Variabel independen berpengaruh terhadap variabel dependen.

Berdasarkan uji signifikansi simultan diatas diketahui bahwa probabilitas sebesar 0.000154 , artinya probabilitas < signifikansi atau $0.000154<$ 0.05 maka dapat disimpulkan bahwa $\mathrm{H}_{0}$ ditolak Sehingga variabel independen secara berpengaruh signifikan terhadap variabel dependen. Artinya variabel independen intellectual capital secara simultan mempengaruhi variabel dependen yaitu Nilai perusahaan .

\section{Hasil Estimasi Koefisien Determinasi Model 1}

Koefisien determinasi $\left(R^{2}\right)$ pada intinya mengukur seberapa jauh kemampuan model dalam menjelaskan variasi variabel dependen. Nilai koefisien determinasi adalah antara 0 dan 1 . Nilai $R^{2}$ yang kecil berarti kemampuan variabelvariabel independen dalam menjelaskan variasi variabel dependen amat terbatas. Nilai yang mendekati 1 berarti variabelvariabel independen memberikan semua informasi yang dibutuhkan untuk memprediksi variasi variabel dependen.
Interpretasi dari output tabel koefisien determinasi dapat dilakukan dengan menganalisa nila RSquare atau nilai Adjusted R Square, namun beberapa ahli menyarankan dapat dilihat dari Adjusted R Square, hal ini karena dengan menggunakan nilai RSquare, nilainya akan berubah jika beberapa variabel independen ditambahkan.

Nilai Ajusted $\mathrm{R}$ Square adalah 2.11670 artinya bahwa kemampua variabel intellectual capital sebesar $21.2 \%$ sedangkan sisanya $78.2 \%$ dipengaruhi oleh variabel lain yang tidak di teliti. Hal ini menunjukan bahwa intellectual capital mampu mempengaruhi nilai perusahaan. Sehingga hasil nya intellectual capital berpengaruh signifikan terhadap nilai perusahaan.

\section{Analisis Regresi Linier Berganda}

Analisis regresi linier berganda digunakan untuk menguji pengaruh dua atau lebih variabel independen terhadap satu variabel dependen (Ghozali, 2011). Berikut persamaan regresi pada kasus moderating, yaitu :

$\mathrm{Y}=\mathrm{a}+\mathrm{b} 1 \times 1+\mathrm{b} 2 \times 1 \times 2+e$.

\section{. Hasil Estimasi Model 2 data panel pengaruh Intellectual Capital terhadap Nilai Perusahaan dengan Strategi Bersaing sebagai Pemoderasi}

\author{
Berdasarkan Tabel diatas \\ Model Regresi Linear Moderasi \\ adalah : \\ $\mathrm{Y}=\mathrm{a}+\mathrm{b} 1 \times 1+\mathrm{b} 2 \times 1 \times 2+\mathrm{e}$ \\ Nilai Perusahaan $=1.471970+$ \\ 0.214295 vaic +0.458145 vaicsb + \\ e
}

Konstanta sebesar 1.471970 menyatakan variabel intellectual capital, intellectual capital dan strategi bersaing sebagai moderasi bernilai nol maka peningkatan nilai perusahaan Perbankan yang ada di Bursa Efek Indonesia naik sebesar 1.471970

Variabel intellectual capital memberikan nilai koefisien sebesar 0.214295 dengan nilai probabilitas 0.0013 lebih kecil dari alpha $0.05(0.0013<0.05)$. 
sementara intellectual capital *strategi bersaing memberikan nilai koefisien 0.458145 dengan nilai probabilitas sebesar 0.0007 lebih kecil dari alpha 0.05 $(0.0007<0.05)$. Berdasarkan hasil yang di peroleh bahwa variabel strategi bersaing sebagai pemoderasi dapat memoderasi hubungan antara intellectual capital dengan nilai perusahaan

\section{Uji Signifikan Parameter Individual (Uji Statistik t) Model 2}

Uji statistik $t$ dilakukan untuk mengetahui sebesrapa besar pengaruh satu variabel independen secara individu dalam menerangkan variabel-variabel dependen. Penelitian ini menggunakan tingkat signifikansi $5 \%$ atau sebesar 0,05. Berikut output hasil uji statistik parsial (uji t) :

\section{Hipotesis pertama Ho ditolak artinya variabel intellectual capital berpengaruh secara signifikan terhadap nilai perusahaan yang ditunjukkan dengan nilai probabilitas lebih kecil dari pada a $5 \%$ $(0.00013>0.05)$ dan strategi bersaing memperkuat pengaruh intellectual capital terhadap perusahaan ditunjukan dengan nilai probabilitas $>0.05(0.0007>0.05)$.}

\section{Uji Signifikansi Simultan (F-test) Model 2}

Secara sederhana $\mathrm{F}$ test dilakukan untuk menunjukkan apakah semua variabel independen atau bebas yang dimasukkan dalam model mempunyai pengaruh secara terhadap variabel dependen. Output uji signifikansi simultan diinterpretasikan dalam tabel 4.12 sebagaimana yang dipaparkan sebelumnya bahwa hipotesis yang diajukan pada uji-F adalah sebagai berikut:

$\mathrm{H}_{0}$ : Variabel independen tidak berpengaruh terhadap variable dependen.

$\mathrm{H}_{1}$ : Variabel independen berpengaruh terhadap variabel dependen.

Berdasarkan uji signifikansi
simultan diatas diketahui bahwa

probabilitas sebesar 0.000034 , artinya probabilitas < signifikansi atau 0.00034 < 0.05 maka dapat disimpulkan bahwa $\mathrm{H}_{0}$ ditolak Sehingga variabel independen berpengaruh signifikan terhadap variabel dependen. Artinya variabel independen intellectual capital secara simultan mempengaruhi variabel dependen yaitu Nilai perusahaan. Dan strategi bersaing sebagai pemoderasi mampu memperkuat pengaruh intellectual capital dengan nilai perusahaan.

\section{Hasil Estimasi Koefisien Determinasi Model 2}

Koefisien determinasi $\left(R^{2}\right)$ pada intinya mengukur seberapa jauh kemampuan model dalam menjelaskan variasi variabel dependen yakni Konservatisme akuntansi. Nilai koefisien determinasi adalah antara 0 dan 1 . Nilai $R^{2}$ yang kecil berarti kemampuan variabelvariabel independen dalam menjelaskan variasi variabel dependen amat terbatas. Nilai yang mendekati 1 berarti variabelvariabel independen memberikan semua informasi yang dibutuhkan untuk memprediksi variasi variabel dependen. Interpretasi dari output tabel koefisien determinasi dapat dilakukan dengan menganalisa nila RSquare atau nilai Adjusted R Square, namun beberapa ahli menyarankan dapat dilihat dari Adjusted R Square, hal ini karena dengan menggunakan nilai RSquare, nilainya akan berubah jika beberapa variabel independen ditambahkan.

Nilai Ajusted $R$ Square adalah 2.34546 artinya bahwa kemampuan variabel intellectual capital sebesar $23 \%$ sedangkan sisanya $77 \%$ dipengaruhi oleh variabel lain yang tidak di teliti. Hal ini menunjukan bahwa intellectual capital mampu mempengaruhi nilai perusahaan. Sehingga hasil nya intellectual capital berpengaruh signifikan terhadap nilai perusahaan dan strategi bersaing mampu memoderasi hubungan antara intellectual capital dengan nilai perusahaan.

\section{Pembahasan}


Pada bagian ini akan membahas mengenai hasil pengujian hipotesis secara statistik dan analisisnya, pembahasan mencakup analisis pengaruh variabel independen terhadap variabel dependen baik secara parsial maupun secara simultan dan pengaruh variabel moderasi.

1. Hasil penelitian ini menunjukan bahwa hipotesis pertama $\mathrm{H}_{1}$ diterima dan menolak $\mathrm{H}_{0}$, dengan kata lain variabel intellectual capital memiliki pengaruh yang signifikan positif terhadap nilai perusahaani, hal ini dapat terlihat dari hasil uji $t$ yang menunjukan nilai koefisien beta 0.022356 dengan nilai probabilitas sebesar 0.0150 artinya variabel intellectual capital signifikan pada a $5 \%(0.0150<0.05)$ dengan demikian $\mathrm{H}_{0}$ ditolak dan $\mathrm{H}_{1}$ diterima. Jadi Penelitian ini sejalan dengan penelitian yang dilakukan oleh putra (2010), Darmawan dan Toro (2012), dan Yunita (2012). Penelitian ini juga sejalan dengan Penelitian Chen et al. (2005), menyatakan bahwa investor cenderung akan membayar lebih tinggi atas saham perusahaan yang memiliki sumber daya intelektual yang lebih dibandingkan perusahaan dengan sumber daya intelektual yang rendah. Harga yang dibayar oleh investor tersebut mencerminkan nilai perusahaan. Market value terjadi karena masuknya konsep modal intelektual yang merupakan faktor utama yang dapat meningkatkan nilai suatu perusahaan (Abidin, 2000). Dalam hubungannya dengan teori stakeholder, dijelaskan bahwa seluruh aktivitas perusahaan bermuara pada penciptaan nilai/value creation. Kepemilikan serta pemanfaatan sumber daya intelektual memungkinkan perusahaan mencapai keunggulan bersaing dan nilai tambah. Investor akan memberikan penghargaan lebih kepada perusahaan yang mampu menciptakan nilai tambah secara berkesinambungan.

2. Hipotesis kedua diterima dengan kata lain variabel strategi bersaing sebagai pemoderasi memperkuat pengaruh antara intellectual capital terhadap nilai perusahaan hal ini dapat di lihat dimana tingkat signifikan strategi bersaing menunjukan nilai 0.0007 , dimana nilai tersebut lebih kecil dari tingkat signifikansi yaitu 0.05 dengan demikian strategi bersaing mampu memoderasi hubungan antara intellectual capital dengan nilai perusahaan berpengaruh terhadap market. Penelitian ini sejalan dengan penelitian Anatan dan Eliton (2005) mengenai strategi inovasi dan kinerja operasional perusahaan dengan melakukan review aplikasi intellectual capital management dalam era baru manufaktur. Dalam penelitian tersebut dikemukakan proposisi bahwa dengan implementasi strategi inovasi yang tepat dalam perusahaan akan mempengaruhi pencapaian keunggulan kompetitif perusahaan.

\section{KESIMPULAN DAN SARAN}

\section{Kesimpulan}

Penelitian ini dilakukan untuk menguji hubungan antara Intellectual Capital dengan nilai perusahaan dengan Strategi Bersaing sebagai pemoderasi. Terdapat dua hipotesis ini. Hipotesis pertama yaitu menguji pengaruh intellectual capital terhadap nilai perusahaan. Berdasarkan hasil penelitian terbukti bahwa intellectual capital berpengaruh negative signifikan terhadap nilai perusahaan. Hasil ini sejalan dengan beberapa temuan dari penelitian sebelumnya yang dilakukan oleh Putra (2010), Darmawan dan Toto (2012), Yunita (2012).

Hipotesis pertama dalam penelitian ini yaitu pengaruh intellectual capital terhadap nilai perusahaan berpengaruh signifikan Pengelolaan IC secara efisien memang diyakini akan meningkatkan nilai pasar bagi perusahaan. Dalam usaha penciptaan value creation diperlukan pemanfaatan seluruh potensi sumber daya yang dimiliki perusahaan meliputi karyawan (Human Capital), asset fisik (Physical Capital) dan structural capital. Value added yang di 
hasilkan akan menciptakan nilai keunggulan kompetitif bagi perusahaan maka persepsi pasar terhadap perusahaan akan meningkat karena di yakini perusahaan yang memiliki keunggulan bersaing mampu bersaing dan bertahan dalam lingkungan bisnis.

Hipotesis kedua dalam penelitian ini yaitu pengaruh Intellectual Capital terhadap nilai perusahaan dengan strategi bersaing sebagai pemoderasi. Berdasarkan pengujian yang di lakukan, diketahui bahwa pengaruh intellectual capital dan nilai perusahaan dengan strategi bersaing sebagai pemoderasi memiliki nilai probabilitas < dari alpha. Hal ini menunjukan bahwa strategi bersaing sebagai pemoderasi mempengaruhi (memperkuat) hubungan antara intellectual capital dengan nilai perusahaan hasil ini sesuai dengan penelitian yang dilakukan Chusnah et al yang menemukan bahwa IC dan kinerja perusahaan dengan strategi bersaing sebagai pemoderasi berpengaruh signifikan.

\section{Keterbatasan Peneliti}

1. Penelitian ini mengukur nilai perusahaan sebagai variabel dependen hanya menggunakan satu proksi saja yaitu PBV (Price Book Value)

2. Sampel dalam penelitian ini berdasarkan jenis industri perbankan saja 3. Terkait dengan strategi bersaing, penelitian ini hanya menguji dari perspektif pemoderasi

4. Hanya meneliti satu variabel independen

\section{Saran}

1. Penelitian selanjutnya dapat menggunakan proksi lain untuk variabel nilai perusahaan seperti EPS (earning per share) karena ada kemungkinan penghargaan investor di cerminkan melalui laba per sham perusahaan atau juga bisa menggunakan lebih dari satu proksi sekaligus.

2. Penelitian selanjutnya diharapkan menjadikan strategi bersaing perusahaan sebagai variabel mediator untuk melihat kemampuan nya dalam

memediasi hubungan antara
intellectual capital dan nilai
perusahaan.

3. Penelitian selanjutnya diharapkan dapat meneliti lebih dari satu variabel independen yang dapat mempengaruhi variabel dependen

\section{REFERENCES}

Barney, J. 1991. Firm Resources and Sustained Advantage. Journal of Management, Vol. 17, pp. 99-120.

Chen, M.-C., Cheng, S.-J., \& Hwang, Y. 2005. An Empirical Investigation of The Relationship Between Intellectual Capital and Firms Market Value and Financial Performance. Journal of Intellectual Capital, Vol. 6 No. 2, pp. 159-176.

Darmawan, M., \& Toro, J. S. 2012. The Impact of Intellectual Capital on Banks Go Public's Market Value and Financial Performance Listed in Indonesia Stock Excahnge (IDX). Fokus Manajerial, Vol. 11 No. 2, 164-182.

Putra, I. C. 2012. Pengaruh Modal Intelektual Terhadap Nilai Perusahaan Perbankan Yang Go Public di Bursa Efek Indonesia. Jurnal IImiah Akuntansi dan Humantika, Vol. 2 No. 1.

Sawarjuwono, T., \& Kadir, A. P. 2003. Intellectual Capital: Perlakuan, Pengukuran dan Pelaporan (Sebuah Library Research). Jurnal Akuntansi \& Keuangan, 5, 35-37.

Bontis, N. 2001. Assessing knowledge assets: a review of the models used to measure intellectual capital. International Journal of Technology Management. Vol. 3 No. 1. pp. 41-60.

Pulic, A. 1998. "Measurng the performance of intellectual potential in knowledge economy". Paper presented at the 2nd McMaster Word Congress on Measuring and Managing Intellectual Capital by the Austrian Team for Intellectual Potential. 
Mavridis, D.G. 2004. "The intellectual capital performance of the Japanese banking sector". Journal of Intellectual Capital. Vol. 5 No. 3. pp. 92-115.

Kubo, I., and A. Saka. 2002. An inquairy into the motivations of knowledge workers in the Japanese financial industry. Journal of Knowledge Management. Vol. 6 No. 3. pp. 262271

Kamath, G.B. 2007. "The intellectual capital performance of Indian banking sector". Journal of Intellectual Capital. Vol. 8 No. 1. pp. 96-123.

Firer, S., and S.M. Williams. 2003. "Intellectual capital and traditional measures of corporate performance". Journal of Intellectual Capital. Vol. 4 No. 3. pp. 348-360.

Canibano, L., Garcia-Ayuso, M., dan Sanchez, P. 2000. Accounting for Intangibles: A Literature Review. Journal of Accounting Literature, 19: 102-130.

Bukh, P.N. C. Nielsen, P. Gormsen, and J. Mouritsen. 2005. "Disclosure of information on intellectual capital in Danish IPO prospectuses". Accounting, Auditing \& Accountability Journal. Vol. 18 No. 6. pp. 713-732.

Edvinsson, L. and M. Malone. 1997. Intellectual Capital: Realizing Your Company's True Value by Finding Its Hidden Brainpower. HarperCollins, New York, NY.

Guthrie, J., and L.D. Parker. 2000. "Intellectual capital: Australian annual reporting practices". Journal of Intellectual Capital. Vol. 1 No. 3. pp. 241-251.

Pulic, A. 1998. "Measuring the performance of intellectual potential in knowledge economy". Paper presented at the 2nd McMaster Word Congress on Measuring and Managing Intellectual Capital by the Austrian Team for Intellectual Potential.
Stewart, T.A. (1997), Intellectual Capital, Nicholas Brealey Publishing, London

Ulum, Ihyaul dkk. 2008. Intellectual Capital dan Kinerja Keuangan Perusahaan; Suatu Analisis dengan Pendekatan Partial Least Square. Simposium Nasional Akuntansi 11 Pontianak.

Lev, B. (2000), New accounting for the new economy, working paper, Stern School of Business, New York University, New York, NY

Tewal, B (2010), Pengaruh Strategi Bersaing dan Inovasi terhadap Kinerja perusahaan Perhotelan di Sulawesi Utara, Jurnal Aplikasi Manajemen

Widarjanto, A.2009. Ekonometrika : Pengantar dan Aplikasinya. Ekonosia, Yogyakarta.

Gujarati, D.N. and D.C. Porter. 2009. Basic Econometrics 5th. Singapore: McGrawHill International Edition

Anatan, T. L., dan Elliton. 2015. Strategi Bersaing Inovasi dan kinerja Operasional Perusahaan: Sebuah review Aplikasi Intellectual Capital Management Dalam Era Baru Manufaktur. Proceeding, Seminar Nsional PESAT 2015.

Chusnah, F. N., Zulfiati, L, dan Supriati D. 2104. Pengaruh Intellectual Capital Terhadap Kinerja Perusahaan dengan Strategi Sebagai Pemoderasi. Makalah Disampaikan Dalam Seminar Nasional Akunatnsi XVII

Yunita, N. 2012. Pengaruh Modal Intelektual Terhadap Kinerja Keuangan dan Nilai Pasar. Accounting Analisys Journal.

Wernelfelt, B,. 1984. A Resource Based View of The Firm. Strategic Management Journal.

Brealey, R. Myers, S. and Allen, F. (2008). Principles of Corporate Finance, 91 h edition, New York: McGraw-Hill.

Sensi, Tribuana Dewi (2005); Analisis Pengaruh Orientasi Bisnis dan Inovasi Produk Terhadap Keunggulan Bersaing Untuk Meningkatkan Kinerja Bisnis. Volume 3 No. 8. ISSN : 1967-9386. 
Abidin (2000), Pelaporan MI: Upaya

Mengembangkan Ukuran-ukuran

Baru. Media Akuntansi, Edisi 7,

Thn. VIII, pp. 46-47

Ang, R. 1997. Buku Pintar Pasar Modal

Jakarta, Mediasoft Indonesia 